Проведеними дослідженнями виникаючих ситуащій небезпечного зближення кількох суден встановлена наявність розподілу суден, які являються суднами-иілями, відносно базового судна. Ці судна-иілі можуть бути небезпечні, безпечні, безпечні, які можуть бути небезпечними за певних умов. В свою чергу, небезпечні для розходження, з якими слід виконати маневр стандартного розходження, а також иілі для розходження, з якими потребуеться маневр екстреного розходження. Доведено, що зазначений розподіл суден можливо провести використовуючи відносність суден-иілей до різних підмножин які залежать від їх відносних параметрів руху до базового судна. Завдяки цьому стало можливим розглядати групу із кількох суден як множину цілей.

Експериментальними дослідженнями з використанням комп'ютерного моделювання підтверджено, що можлива декомпозиція ситуації зближення суден, що склалася, на підмножини, кожна з якої відрізняеться від іншої параметрами відносного руху. Цими параметрами є відносні курс, пеленг, гранично-допустима дистанція найкоротшого зближення для звичайного та екстреного маневрування, термін часу до настання положення дистанції найкоротшого зближення. Співвідношення ивидкостей базового судна та судна-цілі, співвідношення дистанцій найкоротшого зближення $і$ гранично-допустимої дистаниії також впливають на належність до певної підмножини.

Це дозволяє стверджувати, що існує чітка залежність вірогідності зіткнення суден від їх належності до різних підмножин, яка може бути розрахована для кожного судна-учасника маневру розходження. Показано, що при виконанні маневру розходження базовим судном змінюються параметри відносного руху, відповідно $і$ належність оточуючих суден-цілей до різних підмножин.

Таким чином, є підстави стверджувати, що використовуючи зазначену класифікацію суден-цілей може бути розрахована попередньо прогнозована належність суден до різних підмножин. Вірогідність виникнення ситуації небезпечного зближення та/або зіткнення суден також може бути розрахована для кожної зміни курсу базового судна відносно кожного із оточуючих його суден-цілей

Ключові слова: безпека судноводіння, попередження зіткнення суден, оцінка небезпеки зближення, стратегія розходження

\section{A STUDY OF DECOMPOSITION OF A GROUP OF SHIPS FOR PRELIMINARY FORECASTING OF DANGEROUS APPROACHING}

\author{
Y. Volkov \\ $\mathrm{PhD}$, Senior Lecturer \\ Department of Navigation and \\ Electronic Navigation Systems \\ Kherson State Maritime Academy \\ Ushakova ave., 20, Kherson, \\ Ukraine, 73000 \\ E-mail: yevvolkov@gmail.com
}

\section{Introduction}

For safe navigation, the officer of the watch must have adequate knowledge of the International Regulations for Preventing Collisions at Sea, including rules of navigation and maneuvering, in the event of an emergency situation, when time flies quickly, and the situation changes instantly. In a difficult situation, the navigator must be able to make the only correct decision to avoid collision not only with one but also with several ships.

In real navigation conditions in congested areas, continuous monitoring of surrounding ships is required in order to timely identify the situation of dangerous approaching. Anticipating the occurrence of such a situation in case of a change in the course and/or speed of the base and target ships takes some time. Therefore, simple and reliable methods of analysis and forecasting that can be implemented using modern computer navigation systems are necessary. Such methods are needed to help navigators in making the right decision in the event of dangerous approaching of several ships. The required method should take into account and analyze all factors of the current situation, differentiate groups of ships by their safety/danger, and predict the development of further changes in the navigation situation when performing the collision avoidance maneuver.
The research aimed at supporting the navigator's decision-making to enhance navigation safety in view of the growing speed of modern ships, as well as their number and, accordingly, traffic density, should be considered relevant.

\section{Literature review and problem statement}

In [1], the procedure of choosing the maneuver of collision avoidance of three ships is changed by changing the courses under external control is given. The works [2,3] are devoted to the prevention of ship collisions by the methods of external control of the collision avoidance process using a dangerous area of ship speeds. But the issues of control beyond the zone available for external control remain unresolved.

In [4], the system of coordination of collision avoidance of three dangerous approaching ships is considered. It is shown that the proposed coordination system meets the requirements of Ashby's law of requisite variety. Four areas of mutual duties and behavior of each of the interacting ships in the first area are determined.

In [5], the information system for the simulation of ships with complex dynamic models is developed. This system will provide a new type of maneuver planning and control the implementation of the given maneuver. 
The intelligent system for forecasting the ship motion simulating the learning process of the autonomous control unit created using the artificial neural network is discussed in [6]. The main task of the system is to continuously monitor ship parameters and forecast their values after a certain time. It is possible to use the result of forecasting to warn the navigator of an emerging threat.

The paper [7] deals with the identification of parameters of maneuvering models of ships using the recursive least squares method on the basis of vector support machines. Modeling of ship maneuvering is a difficult task of forecasting the ship maneuverability. Among several basic approaches to estimating ship maneuvering models, system identification in combination with the full-scale or free model test is predominant. However, this method seriously depends on the objects of study and initial values of the identified parameters.

The multi-objective Ant Colony Optimization (ACO) algorithm for ship's trajectory planning is the subject of research in [8]. This paper presents a new approach to path planning for the ship in the environment with static and dynamic obstacles.

In [9], it is shown that the ship collision risk index is the main indicator of ship collision avoidance. Advantages and shortcomings of different methods of calculating the ship collision risk index are analyzed in this paper. According to the considered model, the calculation of the collision risk index is constructed for situations of multi-commands of ships in the form of a three-dimensional presentation of the spatial risk index curve, which requires a single microcomputer chip, which should be used for the decision-making system to ensure safe navigation.

Due to incomplete or dominating information, ship collision or dangerous approaching at sea, often caused by a human error, as noted in [10], becomes an increasingly important problem with the growth of maritime traffic. The principles of complete external control of the collision avoidance process are the basis of approaches to forming, with the help of expert knowledge, safe ship trajectories, provided to navigators and ship traffic services. The author, in contrast, proposes the procedure of ship trajectory planning using specialized algorithms for their coordination through preliminary agreements. However, the dependence on preliminary agreements and ship traffic services, the great influence of the human factor make it impossible to widely use this technique.

Despite the practical significance of the results obtained in the above works, the issue of preliminary forecasting of changes in the navigation situation is not sufficiently considered. The unresolved issue is the identification of dangerous approaching to other ships during maneuvering of the base ship.

Therefore, there are reasons to believe that the assessment of changes in the navigation situation, which may occur after the maneuver, before maneuvering will ensure maneuver safety. Assessment of the predicted situation, prevention of dangerous approaching, loss of time and resources necessitate research in this direction.

\section{The aim and objectives of the study}

The aim of the study is to increase navigation safety by developing means to support the navigator's decision-mak- ing on determining the safety of the planned maneuver of collision avoidance with respect to surrounding ships.

To achieve the aim, the following objectives were set:

- to develop a simple and reliable method to classify several target ships surrounding the base ship according to possible threat such as dangerous approaching or collision;

- to determine, using the developed classification of ships, the mechanism of forecasting the situation of dangerous approaching to the third ships when performing the maneuver of collision avoidance with a dangerous target ship by altering the course and/or speed of the base ship.

\section{Materials and methods of studying the interaction of the base ship with the surrounding target ships}

The local proximity of ships, which belongs to the control area $S_{c}$ of the base ship and covers the surrounding area, allows considering their set, which arose on the principle of local proximity of ships and their belonging to the area $S_{c}$ [12]. Thus, the area, events and group of ships that are or may be participants in the collision avoidance maneuver are the set $M$ at the current time.

Suppose in the navigation area of the base ship there are $\mathrm{n}$ targets that create the set $M$ (Fig. 1). The navigator's competence implies accurate characterization of the collision safety situation and distinguishing of targets as dangerous and safe but dangerous under certain conditions. The target ships should also be divided into targets, for which standard or emergency collision avoidance maneuver is required.

To analyze the current situation, information such as bearing, distance, maximum allowable closest point of approach for normal and emergency maneuvering is used. Additional information for full analysis is the time until reaching the closest point of approach, the speed ratio of the base and target ships, the closest point of approach $l_{\text {imin }}$ and the maximum allowable distance $l_{l d}$.

Therefore, to solve the problem, the following methods were applied:

- theoretical mechanics for drawing up differential equations of ship motion;

- mathematical analysis for solving equations of ship motion and finding the dependence of ship motion parameters on control actions.

In this case, each of the targets is characterized by the position relative to the base ship - bearing $\alpha_{i}$ and distance $l_{i}$, as well as the parameters of true motion with the speed $V_{i}$ and course $K_{i}$. The current situation can be formalized using the $n$-dimensional vector $Q$, with each measurement $\mathrm{q}_{\mathrm{i}}$ containing four components $q_{i}=\left(\alpha_{i}, l_{i}, V_{i}, K_{i}\right)$. The situation of approaching of the base ship with $n$ targets can be formalized as the set of targets $\mathrm{M}$, the decomposition of which should be conducted to analyze the emergence of dangerous approaching. The decomposition of the set of targets $M$ should be carried out depending on the risk of collision of the base ship with each of them. The first set of targets $M_{1}$ (Fig. 2) includes the targets $C_{i}$ that move away from the base ship $C_{0}$, with any change in the course of the target of this subset and constant motion parameters of the base ship, the distance $l_{i}$ does not decrease.

The second subset of targets $M_{2}$ (Fig. 3) includes those the distance $l_{i}$ to which increases, but with constant motion parameters of the target of this subset, for any course of the base ship $K_{0}$, the distance $l_{i}$ does not decrease. 


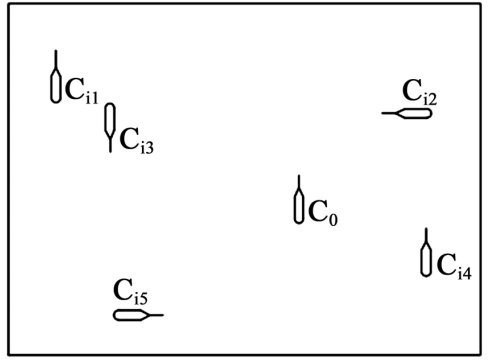

Fig. 1. Group of ships in the navigation area of the base ship $C_{0}$

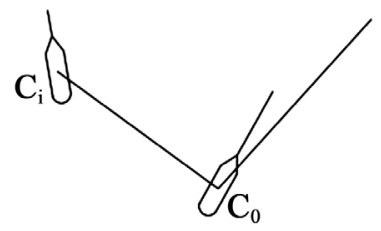

Fig. 2. Motion parameters of the base and target ships: $K_{0}=10^{\circ}, V_{0}=18 \mathrm{kn}, K_{i}=350^{\circ}, V_{i}=11 \mathrm{kn}, \alpha=300^{\circ}$

The third subset of targets $M_{3}$ (Fig. 4) is also characterized by the fact that

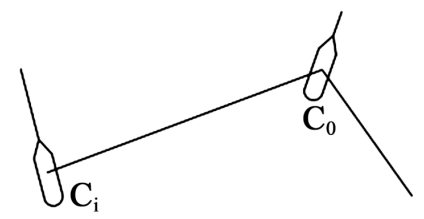

Fig. 3. Motion parameters of the base and target ships: $K_{0}=10^{\circ}, V_{0}=11 \mathrm{kn}, K_{i}=350^{\circ}, V_{i}=18 \mathrm{kn}, \alpha=250^{\circ}$

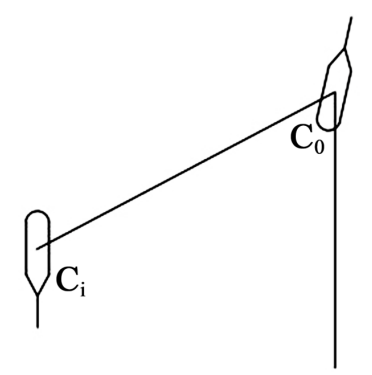

Fig. 4. Motion parameters of the base and target ships: $K_{0}=10^{\circ}, V_{0}=15 \mathrm{kn}, K_{i}=180^{\circ}, V_{l}=18 \mathrm{kn}, \alpha=220^{\circ}$

The remaining subsets of targets are characterized by the fact that the target ships approach the base ship, but they can be differentiated on the basis of collision danger. It is known that the degree of approaching danger of ships is characterized by the maximum allowable closest point of approach. In [11, 12], it is proposed to consider two values of the maximum allowable closest point of approach for the cases of normal and emergency maneuvering, which are respectively designated through $l_{1 d}$ and $l_{2 d}$. The fourth subset $M_{4}$ (Fig. 5-7) includes the targets, the distance $l_{i}$ to which decreases, but the closest point of approach $l_{i \min }$ is more than the maximum allowable distance, that is, the relative motion of ships is safe.

Further subsets include only those targets that create the risk of collision. The next, fifth, subset $M_{5}$ (Fig. 8) includes the targets with which the ship is in the first area of mutual duties. This means that at the moment the base ship does not have to make the collision avoidance maneuver (for example, its maneuver will be hardly noticeable).

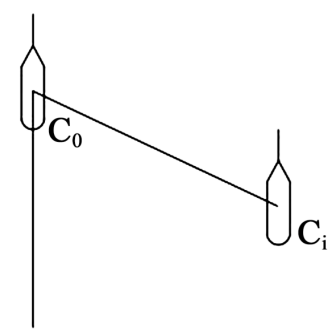

Fig. 5. Motion parameters of the base and target ships: $K_{0}=0^{\circ}, V_{0}=14 \mathrm{kn}, K_{i}=0^{\circ}, V_{i}=18 \mathrm{kn}, \alpha=120^{\circ}$

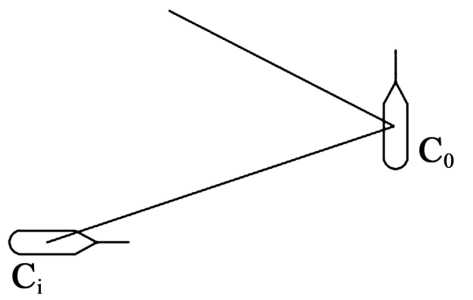

Fig. 6. Motion parameters of the base and target ships: $K_{0}=0^{\circ}, V_{0}=16 \mathrm{kn}, K_{l}=90^{\circ}, V_{i}=20 \mathrm{kn}, \alpha=250^{\circ}$

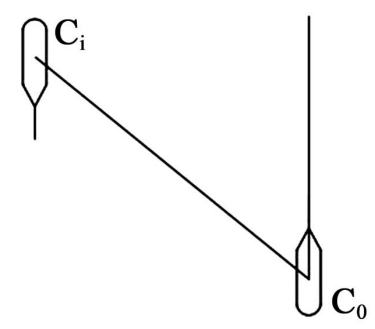

Fig. 7. Motion parameters of the base and target ships: $K_{0}=0^{\circ}, V_{0}=16 \mathrm{kn}, K_{i}=180^{\circ}, V_{i}=14 \mathrm{kn}, \alpha=310^{\circ}$

The sixth subset $M_{6}$ (Fig. 9) includes targets in the second area of mutual duties, in which the base ship must give way, and the target ship - follow with unchanged motion parameters.

In the third area of mutual duties, the base ship is obliged to give way, and the target ship, if it deems it necessary, can make the collision avoidance maneuver on its own. The targets in the third area of mutual duties form the seventh subset $M_{7}$ (Fig. 10).

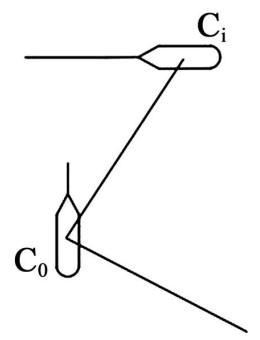

Fig. 8. Motion parameters of the base and target ships: $K_{0}=0^{\circ}, V_{0}=8 \mathrm{kn}, K_{l}=270^{\circ}, V_{l}=18 \mathrm{kn}, \alpha=18^{\circ}$

The eighth subset $M_{8}$ (Fig. 11) is the targets in the fourth area of mutual duties, the area of emergency maneuvering, when both interacting ships must take urgent measures to prevent collision. 


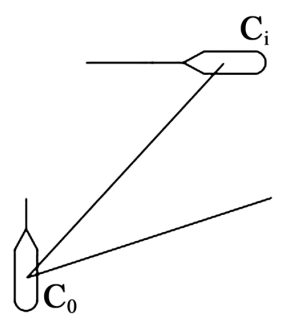

Fig. 9. Motion parameters of the base and target ships: $K_{0}=0^{\circ}, V_{0}=10 \mathrm{kn}, K_{i}=270^{\circ}, V_{i}=20 \mathrm{kn}, \alpha=42^{\circ}$

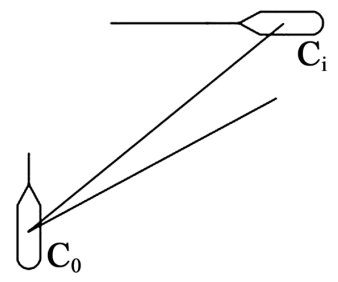

Fig. 10. Motion parameters of the base and target ships: $K_{0}=0^{\circ}, V_{0}=10 \mathrm{kn}, K_{l}=270^{\circ}, V_{l}=20 \mathrm{kn}, \alpha=50^{\circ}$

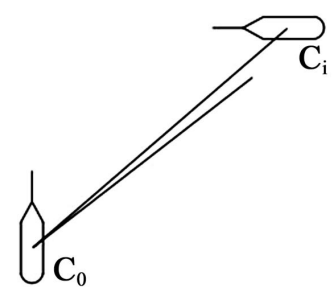

Fig. 11. Motion parameters of the base and target ships: $K_{0}=0^{\circ}, V_{0}=16 \mathrm{kn}, K_{i}=270^{\circ}, V_{l}=20 \mathrm{kn}, \alpha=50^{\circ}$

Thus, the set of the surrounding targets $\mathrm{M}$ contains a certain number of subsets, at least one of them. The analysis of the proposed decomposition of the set of targets $M$ into subsets shows that the decomposition is carried out according to the following parameters:

1. The nature of changes in the distance between the base and target ships (increase or decrease). By this parameter, the decomposition into the subsets $M_{1}, M_{2}$ and $M_{3}$ is performed, which corresponds to the increase in the distance $\left(\partial l_{i} / \partial t \geq 0\right)$ and the subsets $M_{4}, M_{5}, M_{6}, M_{7}$ and $M_{8}$, for which $\partial l_{i} / \partial t<0$.

2 . The possibility to change the increase in distance by maneuvering of the base ship or the target for $\partial l_{i} / \partial t \geq 0$, which allows the decomposition into the subsets $M_{1}, M_{2}$ and $M_{3}$.

3 . The ratio of the closest point of approach $l_{i \min }$ to the maximum allowable distance $l_{1 d}$, which allocates the subset $M_{4}$, for $l_{i \min }>l_{1 d}$ from $M_{5}, M_{6}, M_{7}$ and $\mathrm{M}_{8}$.

4. The belonging of the target and the base ship to a certain area of mutual duties, this parameter is used for the decomposition into the subsets $M_{5}, M_{6}, M_{7}$ and $M_{8}$.

We give analytical expressions for the decomposition of the initial set of ships $M$ into subsets according to the considered features. In [11, 12], it is shown that for $\cos \left(K_{o t i}-\alpha_{n i}\right)>0$, the current distance between the ship and the target is reduced, and for $\cos \left(K_{o t i}-\alpha_{n i}\right)<0$, the current distance increases. Therefore, for the decomposition of the initial set, it is necessary to perform the analysis of the sign of the expression $\cos \left(K_{o t i}-\alpha_{n i}\right)$ for each of the targets. For the targets with $\cos \left(K_{o t i}-\alpha_{n i}\right)<0$, that is, for the subsets $M_{1}, M_{2}$ and $M_{3}$, the parameter of the subsequent decomposition is the possibility to change the sign of the expression $\cos \left(K_{o t i}-\alpha_{n i}\right)$ by changing the course of the target or the base ship. If the target speed $V_{i}$ does not exceed the projection of the base ship speed $V_{0}$ on the bearing direction, the target will not be able to reduce the distance to the base ship, that is, the expression $V_{i}<V_{0} \cos \left(K_{0}-\alpha_{n i}\right)$ should be fair.

In this case, the target corresponding to the above condition belongs to the first subset $M_{1}$. Similarly, the base ship will not be able to reduce the distance to the target if its speed is less than the projection of the target speed on the bearing direction, that is: $V_{0}<V_{i} \cos \left(K_{o}-\alpha_{n i}\right)$. Obviously, all the targets for which this relation is valid belong to the subset of the targets $M_{2}$. If the target parameters do not satisfy either of the conditions $V_{i}<V_{0} \cos \left(K_{0}-\alpha_{n i}\right)$ and $V_{0}<V_{i} \cos \left(K_{0}-\alpha_{n i}\right)$, then the target belongs to the subset $M_{3}$, when the maneuver of the base ship or the target may reduce the distance that first increased. Further decomposition involves obtaining subsets of the targets that approach the base ship. The corresponding parameter is the ratio of the closest point of approach $l_{i \text { min }}$ and the maximum allowable distance $l_{1 d}$. Moreover, if the inequality $l_{i \min }>l_{1 d}$ holds, the target refers to the subset $M_{4}$. Taking into account that the closest point of approach $l_{\text {imin }}$ is determined by the known expression [11, 12]:

$$
l_{i \min }=l_{n i} \sin \left(K_{o t i}-\alpha_{n i}\right)
$$

the condition of belonging of the target to the subset $M_{4}$ takes the form:

$$
l_{n i} \sin \left(K_{o t i}-\alpha_{n i}\right)>l_{1 d} .
$$

If the given condition is not met, the target belongs to one of the subsets $M_{5}, M_{6}, M_{7}$ and $M_{8}$ that characterize the targets that create a collision risk. The belonging of the target to one of the four subsets determines the area of mutual duties of the base ship and the target. As an example, characterizing the further decomposition into the subset $M_{5}, M_{6}, M_{7}$ and $M_{8}$, the ratio of the time of the closest approach $t_{i m i n}$ to the $i$-th target with the values $t_{i 1}, t_{i 2}$ and $t_{i 3}$ is used. The values $t_{i 1}, t_{i 2}$ and $t_{i 3}$ depend on the maximum allowable distances $l_{1 d}$ and $l_{2 d}$, as well as on motion parameters and relative position of the base ship and the i-th target. It is known [11, 12] that:

$$
t_{i \min }=\frac{l_{n i} \cos \left(K_{o t i}-\alpha_{n i}\right)}{V_{o t i}},
$$

where $V_{\text {ot } i}$ is the relative speed with the $i$-th target.

If the following inequality holds:

$$
\frac{l_{n i} \cos \left(K_{o t i}-\alpha_{n i}\right)}{V_{o t i}}>t_{i 1}
$$

the target belongs to the subset $\mathrm{M}_{5}$.

If the following inequality holds:

$$
\frac{l_{n i} \cos \left(K_{o t i}-\alpha_{n i}\right)}{V_{o t i}}>t_{i 2},
$$

the target belongs to the subset $\mathrm{M}_{6}$, characterizing the second area of mutual duties of the ships.

If the following inequality holds:

$$
t_{i 2}>\frac{l_{n i} \cos \left(K_{o t i}-\alpha_{n i}\right)}{V_{o t i}}>t_{i 3},
$$

the target belongs to the subset $\mathrm{M}_{7}$. 
The belonging of the target to the last of these subsets $\mathrm{M}_{8}$ is determined by the inequality:

$$
t_{i 3}>\frac{l_{n i} \cos \left(K_{o t i}-\alpha_{n i}\right)}{V_{o t i}}
$$

belonging to the targets in the area of emergency maneuvering.

\section{Results of the study of decomposition of the set of targets for preliminary forecasting}

Thus, each of the targets surrounding the ship belongs to one of the considered eight non-intersecting subsets, ordered by the degree of danger, targets belonging to the ship.

The next step in analyzing the situation that arose in a certain area based on the principle of local proximity of ships, with the approaching of the base ship to several targets is the choice of collision avoidance maneuver. When choosing a maneuver, consideration should be given to a change in the belonging of ships to different subsets and the possibility of new dangerous targets that require standard or emergency maneuvering to prevent collision.

Consider the situation shown in Fig. 12, where the base ship $C_{0}$, in accordance with rule 15 of the COLREG-72, should give way to the target ship $C_{i 2}$. Following rule 8 (c) of the COLREG-72, the base ship must alter course to starboard to avoid collision with the ship $C_{\mathrm{i} 2}$ (Fig. 10).

In the situation shown in Fig. 12, there is a likelihood of dangerous approaching to the target ship $C_{i 4}$ after course alternation. The target ship $C_{i 4}$, which belonged to the fourth subset $\mathrm{M}_{4}$, changes its belonging from the subset $M_{i 4}$ to $M_{5}$, $M_{6}, M_{7}$ and $\mathrm{M}_{8}$. The belonging to the subset depends on the closest point of approach and the ratio of the time of the closest approach.

The consistent implementation of the maneuver of collision avoidance of the base and target ships, in accordance with the COLREG-72 rules, in the situation (Fig. 12) with several ships in the maneuvering area will result in moving of the base ship to its original position. In this case, a situation of repeatability occurs $\left(C_{01}, C_{02}, C_{03}, C_{04}, C_{05}, C_{06}\right.$, Fig. 12$)$, which returns the risk of collision of the base ship with the target ship $C_{i 2}$.

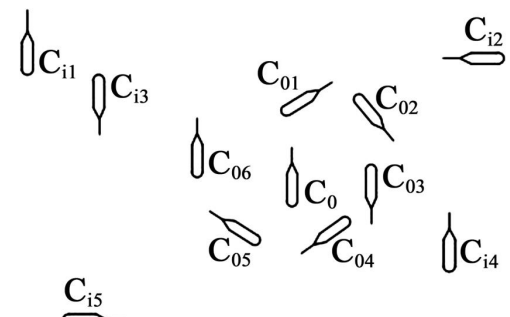

Fig. 12. Maneuvering of the base ship $C_{0}$ to prevent collision

Consideration of a group of ships as a set, the decomposition of which can be carried out by dividing the target ships into subsets on the basis of danger, allows preliminary forecasting. Exactly preliminary forecasting, because if we are talking about forecasting, we mean the possible development of the current event that occurs or has occurred. Preliminary forecasting is absolutely different. This means the possible development of an event that has not yet occurred, but only is planned in the current period of time.
Preliminary forecasting will allow choosing the right collision avoidance maneuver, preventing repeatability and turning into a dangerous approaching position.

\section{Discussion of the results of the study of preliminary forecasting of dangerous approaching based on the belonging of ships to certain subsets}

The application of the above method of ships decomposition requires consideration of dangerous approaching factors and differentiation of ships on the basis of safety/danger. The use of modern computer software will provide the effectiveness of preliminary forecasting. All this will make it possible to predict the belonging of each ship in a group to a certain subset $M_{1-8}$ for any change in the base ship course.

Assessment of the possibility of the dangerous approaching situation when planning the collision avoidance maneuver in a group of ships is carried out by forecasting the development of approaching danger in case of a maneuver, that is, before maneuvering. Such forecasting allows choosing the type of maneuver, namely collision avoidance by changing the course, speed, membership of target ships, for each possible value of the course of the base ship. The choice of collision avoidance maneuver, namely the avoiding course and/or speed, is the subject of further research.

Fig. 13 shows the principle of determining the danger of target ships on each of the possible courses of the base ship by referring them to certain subsets $M_{1-8}$ and the emergence of sectors on the basis of danger. The sectors $(A, B, C, D)$ that arose on the basis of belonging of the target ship to a certain subset, characterize the presence of the threat of dangerous approaching and its degree. The boundaries of the sectors $(A, B, C, D)$ are the limits of the change in the belonging of the target ship to a certain subset determined by the proposed analytical expressions of conditions and can be calculated in advance for each possible course of the base ship. All this allows planning a collision avoidance maneuver, the essence of which is to prevent the target ship from entering the subsets $M_{6}, M_{7}$ and $M_{8}$ on a certain course of the base ship.

Fig. 14 shows the fragment of the approaching situation, discussed in Fig. 13, which shows the change in the belonging of the target ships $C_{i 2}$ and $C_{i 4}$ to certain subsets in the group of ships during maneuvering. The target ship $C_{i 2}$ changes the subset $M_{7,8}$ for the subset $M_{4}$, and $C_{i 4}$ - the subset $M_{4}$ for the subset $M_{7,8}$ in case of change in the course of the base ship. The change in the belonging to subsets can be calculated in advance, with a certain step, for each of the possible courses of the base ship.

In Fig. 14, the numbers 1, 2, 3, 4 indicate the lines of relative dangerous courses that should be avoided and in which there is a change in the belonging to certain subsets.

Preliminary analysis will allow saving time, fuel, motor resources and avoiding dangerous maneuvering.

After analyzing the situation with the participation of several ships, we predict the further change in the belonging of ships to the subsets described above. The emergence of a new threat of collision with other ships, when performing the collision avoidance maneuver by course alternation, shows that the collision avoidance maneuver by speed change, in order to prevent collision, will be the only correct decision in such circumstances. 
Thus, the obtained analytical expressions of the conditions, under which the target ships belong to different subsets by danger and its degree, can identify the emergence of dangerous approaching when maneuvering in a group of ships. Such identification solves the issue of preliminary forecasting of changes in the navigation situation and ensures the safety of the planned maneuver.

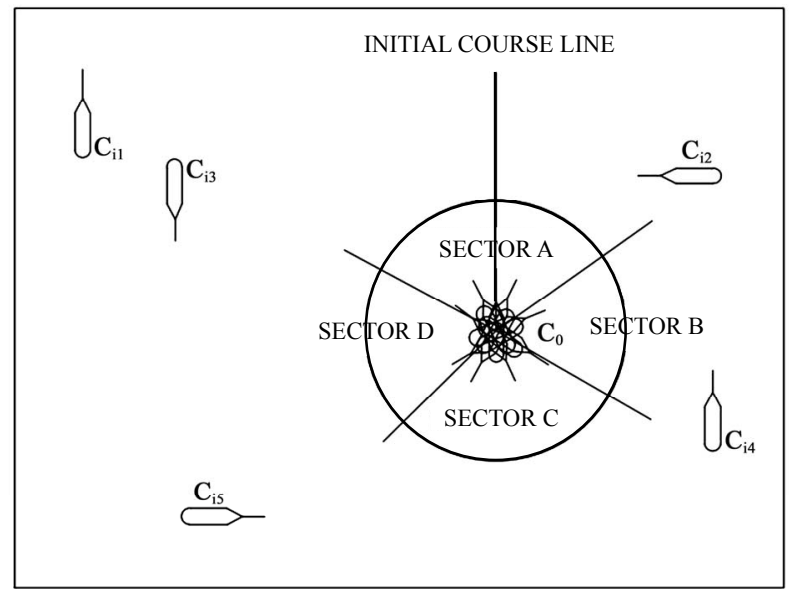

Fig. 13. Determination of the danger of target ships on each of the possible courses of the base ship

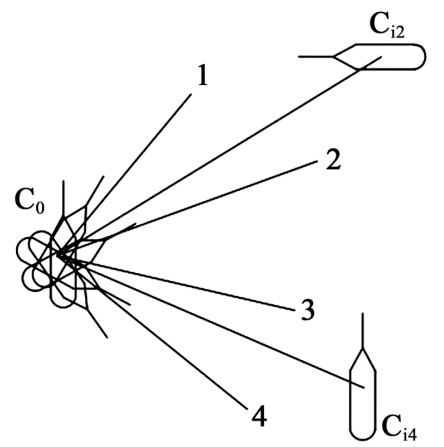

Fig. 14. Change of the belonging to subsets during maneuvering

In contrast to the existing means to support the navigator in difficult maneuvering conditions, with a lack of time to make a decision, the proposed method considers maneuvering in a group of ships. The proposed method gives the opportunity to choose a maneuver of collision avoidance, taking into account the subsequent change in navigation situation, not with one, but with several ships at the same time.

However, when performing the turning maneuver, it should be taken into account that the closest point of approach is less, and the approaching of ships can become dangerous, since the inertia of the ship when turning is not considered. Under the influence of inertia, the ship with the target will separate not at the maximum allowable distance, but by the amount of inertial wear closer.

The consideration of the ship inertia when performing the collision avoidance maneuver and the development of a method for choosing the avoiding course and/or speed while maneuvering in a group of ships is a promising direction for further research.

\section{Conclusions}

1. The conducted studies revealed the mechanism of analysis and forecasting of the development and change of the situation of dangerous approaching of ships in the navigation area of the base ship in the presence of several target ships. The analysis and forecasting can be realized through a methodology that lies in considering a group of ships formed on the principle of local proximity and belonging to a particular navigation area $S$ as a set $M$. Consequently, it is possible to decompose a set $M$ into subsets based on the danger of target ships to the base ship and argue that identification of dangerous targets before the maneuvering will enhance the safety of navigation.

2 . The method for analyzing the current situation of maneuvering of the base ship in a group of target ships is developed. The application of the analytical expressions of the conditions, under which target ships refer to different subsets based on danger, makes it possible to obtain a preliminary forecast of dangerous approaching or threat of collision with other ships.

The practical significance of the results obtained is the possibility of implementing, with the help of a computer program, this methodology with further integration into the complex of an automated navigational bridge. Such a program will promptly inform the navigator of the danger of approaching of the base ship with any of the ships in a group on each of the possible courses without maneuvering. The proposed methodology will also allow characterizing the degree of approaching danger: it can be dangerous on certain courses; dangerous - requires a collision avoidance maneuver: dangerous - requires an emergency collision avoidance maneuver.

References

1. Bulgakov A. Yu., Alekseychuk B. M. Manevr raskhozhdeniya trekh sudov s izmeneniem ih kursov // Problemy tekhniky: Naukovovyrobnychyi zhurnal. 2014. Issue 1. P. 75-81.

2. Burmaka I., Kalynychenko G., Kulakov M. Warning of collisions of vessels by the methods of external control of process of divergence // Science and Education a New Dimension. Natural and Technical Sciences. 2017. Vol. 14, Issue 132. P. 56-60.

3. Burmaka I. A., Kulakov M. A., Kalinichenko G. M. Opredelenie dopustimogo mnozhestva manevrov raskhozhdeniya sudov izmeneniem skorostey // Suchasni tekhnolohiyi proektuvannia, pobudovy, ekspluatatsiyi i remontu suden, morskykh tekhnichnykh zasobiv i inzhenernykh sporud: Materialy Vseukrainskoi nauk.-tekh. konf. Mykolaiv: MUK, 2017. P. 21-23.

4. Pjatakov E. N., Kapanskiy S. V., Volkov E. L. Coordination of three ships passing by safely // Sudovozhdenie. 2017. Issue 27. P. $185-193$.

5. Simulation Augmented Manoeuvring Design and Monitoring: a New Method for Advanced Ship Handling / Benedict K., Kirchhoff M., Gluch M., Fischer S., Schaub M., Baldauf M., Klaes S. // TransNav, the International Journal on Marine Navigation and Safety of Sea Transportation. 2014. Vol. 8, Issue 1. P. 131-141. doi: https://doi.org/10.12716/1001.08.01.15 
6. Lacki M. Intelligent Prediction of Ship Maneuvering // TransNav, the International Journal on Marine Navigation and Safety of Sea Transportation. 2016. Vol. 10, Issue 3. P. 511-516. doi: https://doi.org/10.12716/1001.10.03.17

7. Parameter Identification of Ship Maneuvering Models Using Recursive Least Square Method Based on Support Vector Machines / Zhu M., Hahn A., Wen Y., Bolles A. // TransNav, the International Journal on Marine Navigation and Safety of Sea Transportation. 2017. Vol. 11, Issue 1. P. 23-29. doi: https://doi.org/10.12716/1001.11.01.01

8. Lazarowska A. Multi-criteria ACO-based Algorithm for Ship’s Trajectory Planning // TransNav, the International Journal on Marine Navigation and Safety of Sea Transportation. 2017. Vol. 11, Issue 1. P. 31-36. doi: https://doi.org/10.12716/1001.11.01.02

9. Xu X., Geng X., Wen Y. Modeling of Ship Collision Risk Index Based on Complex Plane and Its Realization // TransNav, the International Journal on Marine Navigation and Safety of Sea Transportation. 2016. Vol. 10, Issue 2. P. 251-256. doi: https://doi.org/ 10.12716/1001.10.02.07

10. Trajectory Planning with Negotiation for Maritime Collision Avoidance / Hornauer S., Hahn A., Blaich M., Reuter J. // TransNav, the International Journal on Marine Navigation and Safety of Sea Transportation. 2015. Vol. 9, Issue 3. P. 335-341. doi: https:// doi.org/10.12716/1001.09.03.05

11. Burmaka I. A., Burmaka I. A., Pyatakov E. N. Upravlenie sudami v situatsii opasnogo sblizheniya. Saarbryukken: LAP LAMBERT Academic Publishing, 2016. 585 p.

12. Tsymbal N. N., Tyupikov E. E., Tsymbal N. N. Gibkie strategii raskhozhdeniya sudov. Odessa: KP OGT, 2007. 424 p.

\begin{abstract}
Розглядаються питання підтримки прийняття рішень при розробиі плану розвитку вузу. Це важливо, тому що сучасні тенденції розвитку організації вищої освіти постійно змінюються і ускладнюються. Управління організацією в сучасних умовах стає адаптивним, випереджувальним, стратегічним, що вимагає перегляду інструментів управління. Основою стратегічного планування виступає індикативне планування, яке в свою чергу є формою, вирішальною проблему недосконалої інформації через показники, що описують об'єкт, процес або явище. Ефективне управління діяльністю вищого навчального закладу в рамках планування включає форми $i$ методи формування системи показників, що відображають картину стану організацї.

Процес розробки плану розвитку університету стикається 3 проблемою вибору і ранжирування показників розвитку вищого навчального закладу, охоплює як матеріальні, так і нематеріальні сторони і є багатокритеріальної завданням прийняття рішень. Для вирімення цвого завдання необхідно вибрати метод для підтримки прийняття рішень для формування системи індикативних показників. Оцінювання індикативних показників здійснюється через побудову когнітивної карти, апріорного ранжирування $i$ методу аналізу ієрархій із залученням експертів зі сфери управління вищою освітою. Отримані результати порівнюються з урахуванням переваг $і$ недоліків обраних методів. Прийняте рішення щодо вибору методу формування показників полягає в спільному використанні методу аналізу ієрархій та побудові когнітивної карти. При гібридному застосуванні методів враховується взаємний вплив показників $і$ відповідність показників напрямками розвитку університету. Апріорне ранжування для формування показників застосовувати недоцільно, так як відсутні дані про спільне вплив один на одного декількох досліджуваних показників.

Результати дослідження спрямовані на спрощення процесу прийняття рішень в плануванні: облік вузьких місць при розробці плану розвитку, підвищення якості роботи $і$ навчання, ефективне використання матеріальних і нематеріальних ресурсів

Ключові слова: оцінка, система, показник, управління, стратегія, розвиток, ієрархія, когнітивна карта, рішення
\end{abstract}

UDC 005:389:338.984:354

DOI: $10.15587 / 1729-4061.2019 .169193$

DEVELOPMENT

OF A DECISION-

MAKING METHOD TO FORM THE INDICATORS FOR A UNIVERSITY DEVELOPMENT PLAN

V. Kulikova

$\mathrm{PhD}$, Associate Professor*

E-mail:v4lentina@mail.ru

K. I k I as sova

Doctoral student*

E-mail: kiklasova@mail.ru

A. Kaz a n b a ye va

Doctoral student*

E-mail: akazanbaeva83@gmail.com

*Department of Information and

Communication Technologies

M. Kozybayev North Kazakhstan

State University

Pushkin str., 86, Petropavlovsk, Kazakhstan, 150000

\section{Introduction}

The problems related to ensuring the quality of higher education and sustainable development of regional higher educational establishments of the Republic of Kazakhstan are becoming more relevant. The lack of marketing research into local labor markets, reliable forecasts of the state of external environment for a regional university is accompanied by non-coordinated numerous units of universities in the formation of tasks and activities. Ambiguous assessment of 